\title{
Asymptomatic bacteriuria in early pregnancy: an analysis
}

\section{MuthuPrabha P.*, Ramalakshmi S.}

Department of Obstetrics and Gynecology, Tirunelveli Medical College Hospital, Tirunelveli, Tamilnadu, India

Received: 18 March 2017

Accepted: 21 April 2017

\section{*Correspondence:}

Dr. MuthuPrabha P.

E-mail: drmuthuprabha85@yahoo.com

Copyright: (c) the author(s), publisher and licensee Medip Academy. This is an open-access article distributed under the terms of the Creative Commons Attribution Non-Commercial License, which permits unrestricted non-commercial use, distribution, and reproduction in any medium, provided the original work is properly cited.

\section{ABSTRACT}

Background: Asymptomatic bacteriuria is defined as greater than 100,000 organisms in the urine of a person who lacks symptoms. The objective of present study was to find out the prevalence of asymptomatic bacteriuria (ASB) in women attending the antenatal OPD in a tertiary care centre and to study the effect of screening and treatment on maternal and fetal outcome.

Methods: The study was conducted at OG Department, Tirunelveli Medical College Hospital over a period of ten months from March 2014 to Dec. 2014. Antenatal women at 12-16 weeks were screened by collecting clean catch midstream urine samples and doing routine urine analysis, culture/sensitivity and colony count. Treatment was given to all bacteriaurics with oral cephalexin and for persistent cases with Inj. gentamycin. Repeat culture was done at second and third trimesters.

Results: In this study, the incidence of ASB was found to be $10.8 \%$. It was more common among primi gravida $(13.98 \%)$ and the incidence was found to be high in low socio economic groups $(12.4 \%)$. In present study $E$. coli was $88.88 \%$, Klebsiella $7.4 \%$ and Staphylococcus aureus 3.7\%. Anemia was found in $37.04 \%$ of bacteriurics, preeclampsia in $7.4 \%$, preterm delivery in $14.82 \%$ and low birth weight in $18.5 \%$ of bacteriurics.

Conclusions: Treatment of ASB during pregnancy at the first antenatal visit decreases the incidence of preeclampsia, premature delivery, low-birth weight and perinatal mortality.

Keywords: Antenatal women, Asymptomatic bacteriuria, Maternal and fetal outcome

\section{INTRODUCTION}

Asymptomatic bacteriuria is defined as greater than 100,000 organisms in the urine of a person who lacks symptoms (Schnarr and Smaill). ${ }^{1,2}$ It is present in approximately $5-10 \%$ of the pregnant population and is found to be similar in most countries. ${ }^{3}$

\section{Pathogenesis}

The Urinary tract undergoes significant changes during pregnancy that impact the development of bacteriuria and the natural history of bacteriuria during pregnancy. In nonpregnant women asymptomatic bacteriuria may not be persistent and may be inconsequential. However, in pregnant women, bacteriuria is more likely to be persistent and is associated with the subsequent development of symptomatic Urinary tract infection (UTI).

Physiologic changes of the collecting system affects the development and significance of bacteriuria in pregnancy. Hydroureter of pregnancy begins in the first trimester and progresses until term returning to normal within several weeks after delivery in most women.

During most pregnancies, dilation of the upper collecting system extends down to the level of the pelvic brim. Dilated ureters may contain more than $200 \mathrm{ml}$ of urine and contribute to the persistence of bacteriuria in pregnancy. The influence of hormonal changes is seen in decreased ureteral persistalsis after the second month of 
gestation, with long period of complete atony seen in the seventh and eighth months of pregnancy.

Other factors may also contribute to the development of symptomatic infection later in the course of pregnancy, including increased bladder capacity and longer kidney length. Hormonal changes may also increase susceptibility to UTI. Therefore, a variety of physiologic and anatomic changes in pregnancy contribute to the persistence of bacteriruria in pregnancy and increase the possibility of symptomatic upper tract infection in untreated women, particularly. Therefore, there is a need for routine screening and treatment of all pregnant women for ASB. ${ }^{4-6}$

\section{Epidemiology}

The epidemiology of bacteriuria in pregnancy is similar to that seen in non-pregnant women, in addition, many of the risk factors for bacteriuria in pregnant women are the same as those that contribute to symptomatic UTI in nonpregnant women. The prevalence of asymptomatic bacteriuria in non-pregnant women increases with age at the rate of approximately $1 \%$ for each decade of life.

The prevalence of bacteriuria increases with age and with sexual activity. Other contributing factors include socioeconomic status, history of recurrent UTIs, diabetes, and anatomic or functional urinary tract abnormalities.

The overall prevalence of bacteriuria in pregnancy ranges from less than $2 \%$ to more than $10 \%$.

\section{Microbiology}

The etiologic agents associated with bacteriuria are similar in pregnant and nonpregnant women. Most of the organisms recovered by routine culture techniques continue to be the Coliforms, with Escherichia coli by far the most common, followed by organisms in the Klebsiella-group, Proteus miarbilis, and others in smaller numbers.

Gram-positive organisms including group B Streptococci, recently received more attention as causing bacteriuria and UTIs. Staphylococcus saprophyticus and other coagulase-negative staphylococci are seen in a small percentage of pregnant women but are recognized as important causes of UTIs and urinary tract complications including stone formation.

Improved culture techniques have resulted in the detection of increased numbers of anaerobic and other fastidious microorganisms. The etiologic agents of bacteriuria in pregnant women mirror those in nonpregnant women. In most pregnant women, the presence of bacteriuria usually reflects prior colonization rather than acquisition during pregnancy.

\section{Screening}

If asymptomatic bacteriuria is not treated, about $25 \%$ of infected women subsequently develop acute symptomatics during that pregnancy. Eradication of bacteriuria with antimicrobial agents has been shown to prevent most of these clinically evident infections. Although it is reasonable to perform routine screening for bacteriuria in women at high risk, screening using urine culture may not be cost effective when the prevalence is low. Less expensive tests such as the leukocyte esterasenitrite dip stick have been shown to be cost effective with prevalence of $2 \%$. Millar and associates reported that screening using enzymatic detection of catalase activity in the urine was ineffective. Another approach for the low-risk population is to perform screening cultures selected by historical factors. Complications Associated with ASB include Anemia, Hypertension, Low-birth weight infants, Fetal growth restriction and Preterm delivery

\section{Treatment}

Women with asymptomatic bacteriuria may be given treatment with anyof several antimicrobial regimens. Selection can be on the basis of invitro susceptibilities

Single-dose antimicrobial therapy for bacteriuria has also been used with success. The recurrence rate for all of these regimens is about $30 \%$. Failure of single dose regimens is about $30 \%$. Failure of single dose regimens may be an indication of upper tract infection and the need for more protracted therapy such as nitrofurantoin, 100 $\mathrm{mg}$ at bed time for 21 days. For women with persistent or frequent bacteriuria recurrences, suppressive therapy for the remainder of pregnancy be indicated. One regimen that has been successful is nitrofurantoin $100 \mathrm{mg}$ at bed time

\section{METHODS}

The study was conducted at antenatal OPD of OG dept at Tirunelveli Medical College Hospital over a period of ten months from March 2014 to December 2014. Antenatal women between the age of 17 and 36 years of age were included. Women with no history of taking antibiotics and those without any symptoms suggestive of urinary tract infection were included in the study. Apart from routine investigations during first visit, a midstream clean catch early morning urine sample was collected in a sterile container from them during their first antenatal visit. Samples were sent for routine urine analysis, culture /sensitivity and colony count within a period of two hours. About $0.01 \mathrm{ml}$ of the sample was used on agar plates and looked for aerobic and anaerobic bacterial growth. Specimens which showed 105 or more bacteria per $\mathrm{ml}$ were considered to be significant bacteriuria.

Treatment was given to all patients with significant bacteriuria with oral cephalexin for 7 days. Patients with 
persistent bacteriuria were treated with Inj. Gentamycin for 5 days and repeat culture were found to be negative.

All mothers were followed up regularly till delivery and discharge. Treated mothers had urine cultures repeated once in second and once in third trimesters. Others had repeat culture done once in the third trimester. Maternal and perinatal outcomes were evaluated.

\section{RESULTS}

In this study, the incidence of asymptomatic bacteriuria in antenatal women at their first prenatal visit was found to be $10.80 \%$.

Table 1: Distribution of asympomatic bacteriuria.

\begin{tabular}{|lll|}
\hline Urine Culture & No. of cases & Percent \\
\hline Positive (bacteriurics) & 27 & 10.8 \\
\hline Negative (non-bacteriurics) & 223 & 89.2 \\
\hline
\end{tabular}

There is a high incidence of ASB in the lower socio economic group due to lack of knowledge, low literacy and poor personal hygiene and lack of facilities to maintain hygiene but not statistically significant.

Table 2: Socio economic status.

\begin{tabular}{|llll|} 
Socio economic & $\begin{array}{l}\text { Total no. } \\
\text { of cases }\end{array}$ & Bacteriurics & $\%$ \\
\hline Class III and IV & 77 & 6 & 7.7 \\
\hline Class V & 173 & 21 & 12.14 \\
\hline
\end{tabular}

$\mathrm{P}=0.3811$

The most common causative organism is Escherichia coli accounting for $89 \%$ of cases. The organisms are usually gram negative enteric bacilli.

Table 3: Causative organisms.

\begin{tabular}{|lll|}
\hline Urine Culture & No. of cases & $\%$ \\
\hline E coli & 24 & 88.88 \\
\hline Klebsiella & 2 & 7.4 \\
\hline Staph Aureus & 1 & 3.7 \\
\hline
\end{tabular}

The occurrence of preeclampsia in non bactriurisis not statistically significant.

Table 4: Distribution of preeclampsia.

\begin{tabular}{|llll|}
\hline $\begin{array}{l}\text { Urine } \\
\text { culture }\end{array}$ & $\begin{array}{l}\text { No. of } \\
\text { cases }\end{array}$ & $\begin{array}{l}\text { Pre } \\
\text { eclampsia }\end{array}$ & $\begin{array}{l}\text { Anemia Hb } \\
\text { in gms <10 }\end{array}$ \\
\hline Bacteriurics & 27 & $2(7.4 \%)$ & $10(37.04)$ \\
\hline $\begin{array}{l}\text { Non } \\
\text { bacteriurics }\end{array}$ & 223 & $19(8.5 \%)$ & $72(32.29)$ \\
\hline
\end{tabular}

The occurrence of low birth weight infants appears to be higher in bacteriuric women treated with antibiotics and all infants weighed between 1.6 to $2.4 \mathrm{~kg}$. The difference in low birth weight infants in both groups is not statistically significant. There were two neonatal deaths in non-bacteriuric group all less than $1.5 \mathrm{~kg}$ and all the deaths were due to respiratory distress syndrome.

Table 5: Distribution of low birth weight.

\begin{tabular}{|lll|}
\hline Birth Weight & Bacteriuries & Non bacteriurics \\
\hline 1 to $1.5 \mathrm{~kg}$ & $0(0 \%)$ & $2(0.8 \%)$ \\
\hline 1.6 to $2.4 \mathrm{~kg}$ & $5(18.5 \%)$ & $27(12.10 \%)$ \\
\hline 2.5 to $2.9 \mathrm{~kg}$ & $20(74.1 \%)$ & $132(59.1 \%)$ \\
\hline $3 \mathrm{~kg}$ and above & $2(7.4 \%)$ & $62(27.8 \%)$ \\
\hline P -0.3851 & & \\
\hline
\end{tabular}

\section{DISCUSSION}

250 women attending the antenatal OPD at a tertiary care hospital were screened at 12-16 weeks and were taken for statistical analysis. The prevalence of ASB among this population was $10.8 \%$. This incidence of $10.8 \%$ is similar to the observation of Samad et al, $(6.1 \%)$ Sanandaj et al, (8.95) and Kalandar et al.

ASB was more common among primigravida (13.98\%). This study correlates with observation of Ionade et al, this could be due to low socio economic status, peak sexual activity, poor personal hygienic practices and delayed postcoital micturition.

ASB incidence was high in low socioeconomic group $12.4 \%$ (Secon et al, Akinloye et al). This may be due to the low literacy rates and lack of health awareness. ${ }^{7}$ Studies from Khatak et al and Abdullah showed that $E$. Coli was the commonest. Others include Pootecus, Klebsiella, Staph. aureus, Saprophyticus and Enterococcus. ${ }^{8}$ In present study E. Coli was $88.88 \%$, Klebsiella $7.4 \%$ and Staph $3.7 \%$.

In this study anemia was found in $32.28 \%$ of nonbacteriurics and $37.04 \%$ in bactericurics; Preeclampsia was found in $7.4 \%$ of bacteriurics and $8.6 \%$ nonbacteriurics. This difference is not statistically significant, maybe because of treating the bacteriurics. The incidence of preterm delivery in bacteriurics was $14.82 \%$ and incidence of low birth weight was $18.5 \%$. This shows that diagnosis and treatment of ASB during pregnancy at the first visit decreases the incidence of premature delivery, low birth weight and perinatal mortality

\section{CONCLUSION}

250 antenatal women attending antenatal O.P. at Tirunelveli medical college hospital were screened for asymptomatic bacteriuria at the first antenatal visit between 12-16 weeks of gestation during the period between March 2014 and December 2014 with quantitative urine culture. Both bacteriurics and non bacteriurics were followed upto delivery and the adverse effects of bacteriuria in mother and neonate were observed and analysed. The incidence of ASB in the study group was $10.86 \%$ and it attributed to low 
socioeconomic status of the women. Screening at the first antenatal visit 27 pregnant women were found to be culture positive for bacteria and most were primigravida $(13.98 \%)$ which may be related to sexual activity which favors peri urethral colonization of bacteria.

Among the bacteriurics $74.07 \%$ were primigravida. This shows that these women might have had bacteriuria even before marriage, which has been unmasked by pregnancy changes in the urinary tract. Among the bacteriurics $77.77 \%$ belonged to socioeconomic class $\mathrm{V}$ an important association found in literature.

Pyuria was present in $62.96 \%$ of bacteriurics, which cleared after antimicrobial treatment suggesting infection than mere colonization. No cases of pyelonephritis occurred in both groups suggesting that early screening and treatment of ASB is essential in preventing this complication.

E. coli was the most common causative organism as in various studies worldwide. The incidence of anemia and preeclampsia in both groups was comparable and this study did not show a cause and effect relationship.

The occurrence of low birth weight infants and preterm delivery was reduced similar to that in non bacteriurics suggesting the importance of screening and treatment of ASB during pregnancy

\section{Funding: No funding sources} Conflict of interest: None declared

Ethical approval: The study was approved by the Institutional Ethics Committee

\section{REFERENCES}

1. Smaill F. Asymptomatic bacteriuria in pregnancy. Best Pract Res. 2007;21:439-50.

2. Schnarr J, Smaill F. Asymptomatic bacteriuria and symptomatic and symptomatic urinarytract infections in pregnancy. Eur J Clin Invest. 2008;38(Suppl 2):50-7.

3. Little PJ. The incidence of urinary infection in 5000 pregnant women. Lancet. 1966;2(7470):925-8.

4. Romero R, Oyarzun E, Mazor M, Sirtori M, Hobbins JC, Bracken M. Meta-analysis of the relationship between asymptomatic bacteriuria and preterm delivery/low birthweight. Obstet Gynecol. 1989;73:576-82.

5. Tugrul S, Oral O. Kumru P, Kose D, Alkan A, Yildirim G. Evaluation and importance of asymptomatic bacteriura in pregnancy. Clin Exp Obstet Gynecol. 2005;32:237-40.

6. Imade PE, Izekor PE, Eghafona NO, Enabulele OI, Ophori E. Asymptomatic abacteriuria among pregnant women. North Am J Med Sci. 2010;2(6):263-6.

7. Akinloye O, Ogbolu DO, Akinloye OM, Terryalli OA. Symptomatic bacteriuria in pregnancy in Ibadan, Nigeria: a re-assessment. Br Biomed Sci. 2006;63(3):109-12.

8. Abdullah AA, Al-Moslih MI. Prevalance of asymptomatic bacteriuria in pregnant women in Sharjah, United Arab Emirates. Eastern Mediterranean. Health J. 2005;11(5):1045-52.

Cite this article as: MuthuPrabha $\mathrm{P}$, Ramalakshmi $\mathrm{S}$. Asymptomatic bacteriuria in early pregnancy: an analysis. Int J Reprod Contracept Obstet Gynecol 2017;6:2413-6. 